短報 定型骨髄腫の完成に 25 年以上を要した

\title{
smoldering multiple myeloma
}

\section{一完成前後の経過（続報）と形質細胞の ${ }^{3} \mathrm{HTdR}$ 標識率の意義一}

\author{
京都大学医学部第一内科 加納 正 $\diamond$ 仲正志 大野辰治 内野治人
}

概要 25年以上の定期的観察により smoldering multiple myeloma (S-MM)から定型 (overt) 骨髄腫（MM）に移行する過程を捉えることが出来た. Bence Jones蛋白の出現（BJ escape）， ${ }^{3} \mathrm{HTdR}$ 標識率（LI\%）の上昇，M成分量と骨㖪形質細胞数の増加，次いで骨破壊像の順に定型 MM完成の過程が観察された。とくにLI\%の低いS-MMにおいて，二の值が上昇することは定 型MMへの進展を考慮すへきである。また骨破壊像の出現はこの過程の最終像であるから， 二 れに依存する診断の限界も承知すべきである。

[日内会誌 $76: 146 \sim 147,1987$ ]

先に本誌上に括いで，24年間経過観察した smoldering multiple myeloma (S-MM) 例につ いて報告した際, Bence Jones（BJ）蛋白の出現 （痕跡）と形質細胞の異型性の進展から定型 (overt) 骨髄腫 (MM)への移行が懸念されること を論じた。執筆時点（1985年1月）から数支て約 1 年半後に M成分量と BJ蛋白排せつ量の増量を 伴つて頭蓋骨に打抜き像を認め定型MMの病像を 完成した。ところがこのような病像の変化に先立 つて形質細胞の ${ }^{3} \mathrm{HTdR}$ 標識率 (labeling index, LI\%)の上昇がみられた。再び本誌上を借りて， 定型MMを完成する前後の経過ならびにLI\%の 変動とその意義について論じたい。

症例： 定型MMの完成前の24年間の経過の詳 細については，先の報告”を参照していただきた い. 患者：1922年11月生，女性，無職。経過の 要約(表 1)：1961年，臀血と血清M成分の証明 (IgG型，4.1g/dl)，1979年末で責血症状をとさに 訴える他は主要検査成績の变動を認めず，無症状 に経過した，右反回神経麻㿉(自然消退)，軽度の 腰痛(1980年以降), 転落に上る左下腿骨骨折 (1980
表 1。主要検查成績の経時的変動

\begin{tabular}{lrrrr}
\hline & July '84 & Feb. '85 & Nov. '85 & June ' 86 \\
rotal protein (g/d1) & 8.1 & 7.8 & 7.9 & 8.5 \\
M-component (IgG-K) (g/dI) & 2.9 & 2.8 & 3.0 & 3.5 \\
IgG (mg/d1) & 1,931 & 2.447 & 2.459 & 2.830 \\
IgA (mg/d1) & 41 & 69 & 30 & 29 \\
IgM (mg/d1) & 53 & 64 & 63 & 50 \\
Bence Jones protein (g/day) & trace & trace & trace & 1.5 \\
Bone marrow plasma cells (q) & 7.5 & 5.0 & & 12.2 \\
LI (g) & 0.8 & 5.6 & & 3.2 \\
Hemoglobin (g/d1) & 10.3 & 10.2 & 9.9 & 9.4 \\
Calcium (midi) & 8.4 & & 9.0 & 9.1 \\
Creatinine (mg/dl) & 0.7 & 0.6 & 0.7 & 0.8 \\
Bone lesions & $(-)$ & $(-)$ & $(+)$ & $(+)$ \\
Vertebral collapse & $(-)$ & $(-)$ & $(-)$ & $(+)$ \\
Lytic lesions & & & & \\
\hline
\end{tabular}

年), 春椎後わんと春痛（1984年以降）などを認め たが，春腰痛は定型MMの診断直前まで汪とんど 非進行性であつた。1984年 7 月にはBJ蛋白が痕跡 出現 (BJ escape)を示し，1985年 2 月にはLI\%の 上昇， $\mathrm{M}$ 成分量と骨髄形質細胞数の増加，次いで 骨破壊像の順に定型MM完成の過程が観察され た. 骨破壊像の確認後, 化学療法 (melphalan, prednisolone)に入り, 自他覚症の改善を認めてい る.

考案： MMの診断には骨X線像，骨髄形質細 胞数と形態, $\mathrm{M}$ 成分量, $\mathrm{BJ}$ 蛋白排せつ量, 正常免 疫グロブリンの態度, 貧血の程度などの指標が利

〔昭和61年 8 月28日受稿〕

A case of smoldering multiple myeloma in which a transformation into overt multiple myeloma has been completed more than 25 years later: The course of illness before and after the transformation (a further contribution) and the significance of labeling index of plasma cells

Tadashi Kanoh, Tadashi OhnakA, Tatsuharu Ohno and Haruto Uchino The First Division, Department of Internal Medicine, Faculty of Medicine, Kyoto University, Kyoto 
用されてきた2)。しかし，定型MMと5年後も安定 した経過を示すS-MMを当初から区別することは 困難である。この鑑別を重大な臨床課題とする理 由は，同じMMの診断基準を満足しても後者は当 面化学療法の対象とならないからである゙3. 本例 にみるごとく，一部のS-MMは長年の経過の後に 定型MMに移行し得るが，この過程に関しての詳 細な報告は見当たらない，本例の観察を通じて， 安定期 (smoldering) から進行期 (overt) に移行 する前後の病態変貌について考察し，MMの自然 史の一端をらかがいたい。

(1) BJ escape ${ }^{4)}$ ：骨破壊像を確認する 2 年 前に認め, 病態の悪化を示す最初の指標であつた。 その増量がみられたのは骨破壊の時期に近い，経 過中に出現するBJ蛋白は少量といえどる見逃し てはならないことを教えている。（2）LI\%の上 昇：骨破壊像を確認する 1 年半前に認めた。本 例に㧍いては，LI\%の上昇は以後のM成分量上骨 葡形質細胞数の增加からみてgrowth fractionの 増加を示しているとみられ，腫汮細胞の回転が plateau状態から脱したことを意味する。その後腫 瘍細胞が充分な量に達して後, 臨床上定型MMの 像を呈したと考えられる。LI\%の上昇を示したSMMの定型MMへの䔟行の可能性は既に指摘され ている5．LI\%の上昇は直ちに骨䯣形質細胞数の 増加や，形態变化を伴うとは限らない。なお，本 例にみたLI\%の推移は有意義なるのである，LI\% の算定は 2 人以上によつて行ない，ばらつきが無 視できる程度であることを確認して扣り，このこ とは注かでも指摘されている通りである5．MM 未治療例（6 例）の平均 LI\%は $2.3 \%$ $(1.0 \sim 3.5 \%)$, 治療例（8 例）では $4.9 \%$ (2.6ー10.5\%) であつた。末期MMでtumor burdenが極端に大きくなつたとき，LI\%が低值を示 す場合があるが，1984年の本例と明らかに区別さ れるものである。（3）M成分量と骨䯣形質細胞数 の増加： 先に述べたごとく，これらは腫瘍細胞 がplateau状態を脱して增殖した結果であるから， 当然遅れて出現する指標である．M成分量の変化 を伴わないBJ escapeは腫汮細胞の質的变貌を示 すのに対して4，M成分量の増加は腫湯細胞数の 増大を反映しているとみられる。定型MMの完成 に20年以上要した例としては，ほかにNorgaard の報告例 (24年) ${ }^{6}$ が知られているが，経過の詳細 なデータを示し得た例としては本例が最初のもの であるう。しかし，BJ escape, LI\%の上昇が長年 の安定期の後に発現する機序は全く不明である。 本例に扔いて, triggerとみられる episodeを認め ない，強いて言うならば，加令が考慮される，定 型MMへの進展を反映するこれらの指標の相互関 係は本例のみに適用される性質のものではない が，上り普遍的な原理を求めて同様症例の開発が 期待される。

結語：多発性骨髄腫の自然史を真に理解する ためには，多彩な姿をとる単クローン性免度グロ ブリン血症の経過を長年にわたつて追跡する気構 えが診療に当たる医師に要求される。

\section{文献}

1）加納 正，小屋美津彦：24年間にわたり経過観察 されたsmoldering multiple myeloma 一経過の 詳細と意義一。日内会誌 $75: 98,1986$.

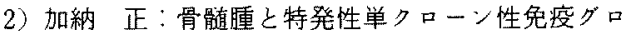
ブリン血症の境界領域をどのように考光るか．日 臨免会誌 $6: 352,1983$.

3) Kyle RA and Greipp PR: Smoldering multiple myeloma. New Engl J Med 302: 1347, 1980

4) Hobbs JR: Monitoring myelomatosis. Arch Intern Med 135: 125, 1975.

5) Greipp PR and Kyle RA: Clinical, morphological, and cell kinetic differences among multiple myeloma, monoclonal gammopathy of undetermined significance, and smoldering multiple myeloma. Blood 62:166, 1983.

6) Norgaard $O$ : Three cases of multiple myeloma in which the preclinical asympto matic phases persisted throughout 15 to 24 years. Brit J Cancer 25: 417, 1971. 